\title{
DYFUZOR RURKOWY SPRĘ̇̇ARKI PROMIENIOWEJ I OSIOWO-PROMIENIOWEJ
}

\begin{abstract}
Niskokosztowy dyfuzor rurkowy powstały w rezultacie wiercenia odrębnych kanałów został rozwinięty przez firmę Pratt \& Whitney dla sprężarek promieniowych i osiowo-promieniowych o wysokiej sprawności. Wymienione oddzielne otwory wierconych kanałów są rozmieszczone w układzie symetrycznym, aby wzajemnie przecinały się w taki sposób, że oś dyfuzora rurkowego jest styczna do okręgu wierzchołków łopatek wirnika sprężarki odśrodkowej. W pracy przedstawiono oryginalną metodę obliczeń parametrów geometrycznych dyfuzora rurkowego oraz propozycję sposobu wyznaczenia parametrów strumienia na wylocie dyfuzora. Wymienione metody (zalecane do projektu koncepcyjnego sprężarki) oparto na twierdzeniu Pitagorasa, równaniu zachowania energii, równaniu ciągłości, pierwszej zasadzie termodynamiki, równaniu momentu ilości ruchu Eulera oraz definicjach stosowanych w teorii maszyn wirnikowych. Zaprezentowano także wyniki nielicznych badań eksperymentalnych tego dyfuzora.
\end{abstract}

Słowa kluczowe: silnik turbinowy, sprężarka, dyfuzor rurkowy

\section{Wprowadzenie}

W wirniku sprężarki odśrodkowej do czynnika roboczego jest doprowadzana praca efektywna, w której duży udział stanowi przyrost energii kinetycznej strumienia $\left(C_{2}>>C_{1}\right)$. Przy sprężu sprężarki $\pi_{S R}{ }^{*}=4$ prędkość bezwzględna na wylocie wirnika sięga wartości $C_{2} \cong 420 \mathrm{~m} / \mathrm{s}\left(M_{C 2} \cong 1,1\right)$, natomiast w przypadku wyższych wartości sprężu $\pi_{S R}{ }^{*}=8,5$ prędkość bezwzględna jest wyższa i wynosi $C_{2} \cong 525 \mathrm{~m} / \mathrm{s}$, co odpowiada liczbie Macha $M_{C 2}=1,2$. Naddźwiękowe prędkości wypływu $\mathrm{z}$ wirnika wymagają stosowania w konstrukcji sprężarki promieniowej efektywnie działających dyfuzorów w celu wyhamowania strumienia powietrza do prędkości niezbędnych ze względu na prawidłowe działanie komory spalania, zwykle $C_{K S} \leq 120 \div 160 \mathrm{~m} / \mathrm{s}\left(0,1<M_{K S} \leq 0,2\right)$. Dyfuzor rurkowy jest klasycznym rozwiązaniem konstrukcyjnym dyfuzora, które ma zastosowanie $\mathrm{w}$ wielu konstrukcjach lotniczych silników turbinowych śmigłowych (PT6A-28 (rys. 1.), PT6A-50) i śmigłowcowych (PT6B, PW 206A) oraz dwuprzepływowych klasy małego ciągu (JT15D-4, PW 308, PW 610) ze sprężar-

\footnotetext{
${ }^{1}$ Autor do korespondencji/corresponding author: Stanisław Antas, Politechnika Rzeszowska, al. Powstańców Warszawy 8, 35-959 Rzeszów, tel.: (17) 8651501, e-mail: santas@ prz.edu.pl
} 
ką osiowo-odśrodkową lub promieniową, produkowanych przez firmę Pratt $\&$ Whitney.

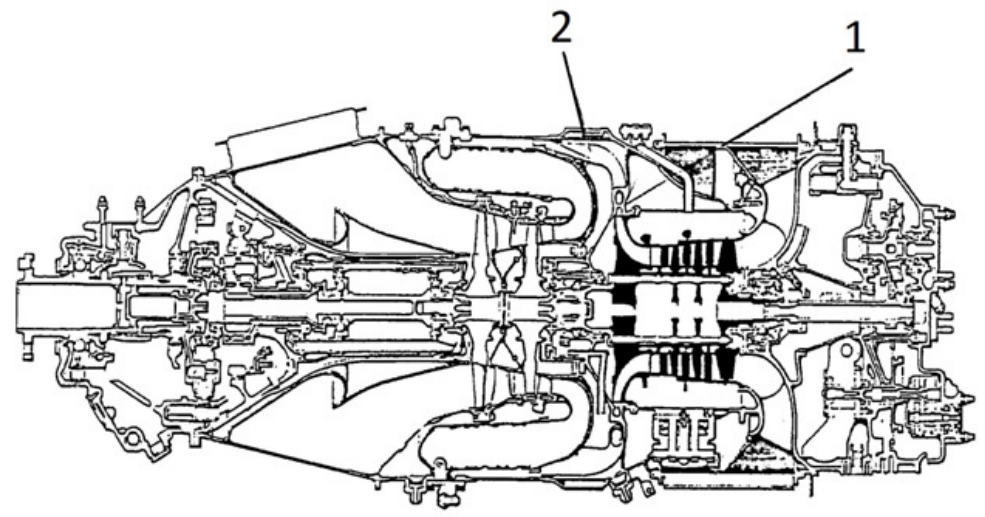

Rys. 1. Przekrój silnika śmigłowego PT6A-28: 1 - kadłub dyfuzora rurkowego, 2 - układ wylotowy sprężarki (dyfuzor zakrzywiony), na podstawie [1]

Fig. 1. Turbo-propeller engine PT6A-28 section: 1 - casing of pipe diffuser, 2 - exhaust system of compressor (controlled-contour diffuser), according to [1]

Należy podkreślić, że w dostępnej literaturze przedmiotu brak zarówno publikacji dotyczących kompleksowej analizy parametrów geometrycznych dyfuzora rurkowego, jak i wyznaczenia parametrów termicznych i kinematycznych strumienia przepływającego przez ten dyfuzor [2-4]. Ograniczona liczba publikacji dotyczy jedynie mniej lub bardziej szczegółowego opisu rozwiązania konstrukcyjnego tego dyfuzora [2, 3, 5-7] na podstawie informacji zawartych w patentach $[8,9]$. Niewielka liczba informacji dotyczących dyfuzora rurkowego zmusiła autora niniejszej pracy do poszukiwania własnej drogi postępowania, która umożliwia operowanie zmianami parametrów geometrycznych i termogazodynamicznych czynnika $\mathrm{w}$ dyfuzorze rurkowym $\mathrm{z}$ dostateczną dokładnością dla praktyki inżynierskiej w projekcie koncepcyjnym sprężarki. W rezultacie spowodowało to konieczność opracowania oryginalnej metody analitycznej.

Dyfuzory rurkowe są szczególnie zalecane do stosowania w sprężarkach promieniowych o sprężu $\pi_{s}^{*}>5$, ich bowiem sprawność jest wyższa od łopatkowych o 6-9\% [3, 4], sięgając wartości 83\% dla wysokich wartości liczb Macha $M_{3}$. Zastosowanie sprężarek promieniowych w konstrukcji silników śmigłowych, śmigłowcowych i dwuprzepływowych wymaga minimalizacji średnic zewnętrznych dyfuzorów w celu uzyskania mniejszej masy sprężarki, w przypadku zaś wykorzystania konwencjonalnego dyfuzora łopatkowego lotniczego silnika dwuprzepływowego dodatkowo prowadzi to do wzrostu ciągu czołowego. Zastosowanie konwencjonalnego dyfuzora łopatkowego przy niskich warto- 
ściach liczby Macha prędkości bezwzględnej na wlocie do komory spalania $\left(M_{K S}<0,2\right)$ pociąga za sobą uzyskiwanie większych średnic kanału wylotowego sprężarki, a zatem przekroju czołowego silnika, niż z wykorzystaniem dyfuzora rurkowego. Autorem patentu dyfuzora rurkowego z 1967 r. jest J.Ch. Vrana, pracownik firmy Pratt \& Whitney [8].

\section{Parametry geometryczne dyfuzora rurkowego}

Dyfuzor rurkowy, zwany także wielostożkowym [7], jest umieszczany za dyfuzorem bezłopatkowym, spełniając rolę dyfuzora łopatkowego. Początkową część dyfuzora stanowi odcinek walcowy (gardziel), za którym znajduje się odcinek stożkowy (rys. 2.). Oś dyfuzora rurkowego powinna być styczna do okręgu wierzchołków łopatek wirnika sprężarki odśrodkowej, tzn. okręgu zakreślonego promieniem $R_{2}$ [8-10]. Wejściowa przednia krawędź kanału dyfuzora rurkowego w rezultacie przenikania skośnego walcowego otworu gardzieli z cylindryczną powierzchnią wlotową dyfuzora o promieniu $R_{3}$ jest trójwymiarowa o zarysie elipsoidalnym (rys. 3.). Umożliwia ona stopniowe dostosowanie strumienia wypływającego z koła wirnikowego, a następnie dyfuzora szczelinowego do przepływu przez część cylindryczną i stożkową dyfuzora. Układ wylotowy sprężarki z dyfuzorem rurkowym stanowi dyfuzor zakrzywiony - promieniowo-osiowy (ang. diffusing trumpet [11], fishtail-shaped diffuser, controlled-contour diffuser [12]). Rysunek 4. przedstawia trzy kanały dyfuzora rurkowego, których osie są styczne do okręgu zakreślonego promieniem $R_{2}$ w punktach $A_{1}, A_{2}, A_{3}$.

Rys. 2. Schemat konstrukcji dyfuzora rurkowego: 1 - punkt styczności osi dyfuzora i okręgu wierzchołków łopatek wirnika, 2 - gardziel kanału dyfuzora rurkowego, 3 - stożek dyfuzora, na podstawie $[4,5]$

Fig. 2. The construction scheme of the pipe diffuser: 1 - tangency point of diffuser axis and the impeller tip of radius, 2 - channel throat of pipe diffuser, 3 - diffuser cone, according to [4, 5] $\mathrm{Na}$ rysunku zaznaczono charak-

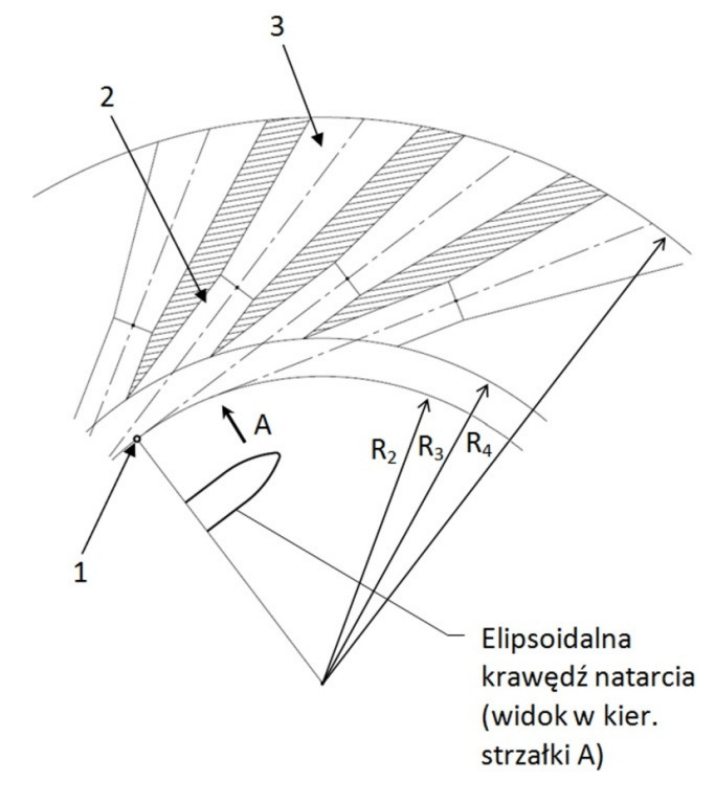


terystyczne parametry geometryczne dyfuzora. Geometria kanału przepływowego dyfuzora rurkowego jest określona przez:

- średnicę wewnętrzną $D_{3}=2 R_{3}$,

- średnicę zewnętrzną $D_{4}=2 R_{4}$,

przy czym średnica wewnętrzna stanowi jednocześnie średnicę wylotową dyfuzora bezłopatkowego, jej wartość określa zaś geometria dyfuzora szczelinowe-

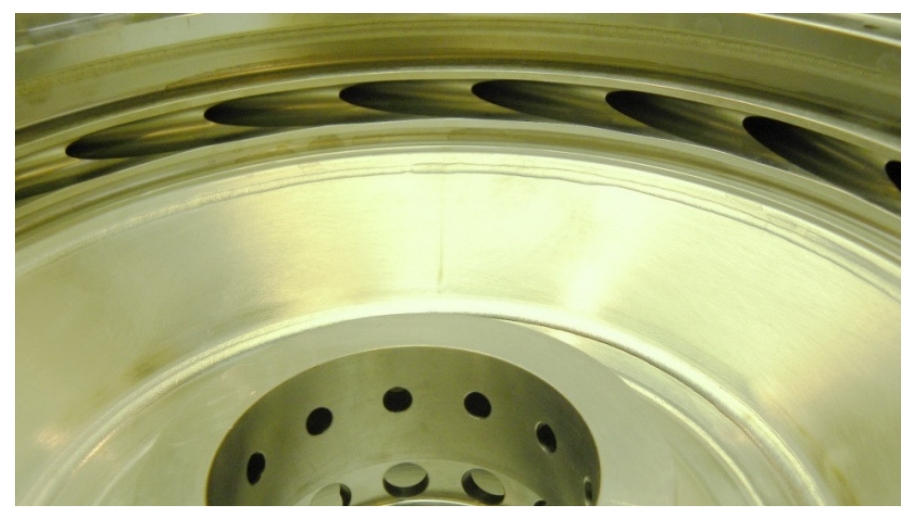

Rys. 3. Widok od strony wirnika elipsoidalnych krawędzi natarcia dyfuzora rurkowego (dzięki uprzejmości firmy Pratt \& Whitney - dar dla Politechniki Rzeszowskiej)

Fig. 3. The view of elliptic leading-edge of the pipe diffuser from the rotor direction (thanks to the courtesy of Pratt \& Whitney - donation for Rzeszów University of Technology)

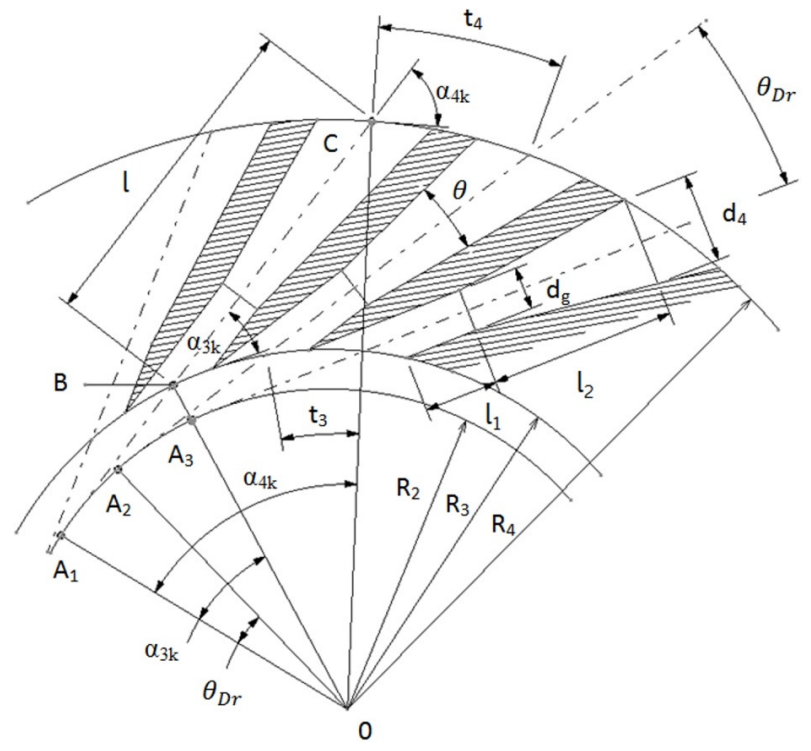

Rys. 4. Charakterystyczne parametry geometryczne dyfuzora rurkowego

Fig. 4. Characteristic geometrical parameters of the pipe diffuser 
go: $D_{3} / D_{2}=1,05 \div 1,1[10,13]$. Średnicę zewnętrzną dyfuzora rurkowego pierwszej i drugiej generacji wyznacza stosunek średnic: $D_{4} / D_{3}=1,20 \div 1,30[1,5,9]$, a w nowszych konstrukcjach $D_{4} / D_{3} \leq 1,15 \div 1,20[1,10,14]$.

Ponieważ osie kanałów przepływowych dyfuzora rurkowego są styczne do okręgu o promieniu $R_{2}$, trójkąty $O A_{1} B$ oraz $O A_{1} C$ są trójkątami prostokątnymi. Wykorzystując twierdzenie Pitagorasa, można zapisać związki z trójkąta $O A_{1} B$ :

$$
O A_{1}^{2}+A_{1} B^{2}=O B^{2}
$$

stąd

$$
A_{1} B=\sqrt{O B^{2}-O A_{1}^{2}}
$$

lecz $O B=R_{3}$, natomiast $O A_{1}=R_{2}$, a zatem:

$$
A_{1} B=\sqrt{R_{3}^{2}-R_{2}^{2}}
$$

$\mathrm{Z}$ trójkąta $O A_{1} C$ wynika relacja:

$$
O A_{1}^{2}+A_{1} C^{2}=O C^{2}
$$

skąd

$$
A_{1} C=\sqrt{O C^{2}-O A_{1}^{2}}
$$

gdzie $O C=R_{4}$, a więc

$$
A_{1} C=\sqrt{R_{4}^{2}-R_{2}^{2}}
$$

Długość osi dyfuzora rurkowego wyznacza odcinek $B C$ :

$$
L=B C=A_{1} C-A_{1} B
$$

Po uwzględnieniu formuł (3) oraz (5) uzyskuje się:

$$
L=\sqrt{R_{4}^{2}-R_{2}^{2}}-\sqrt{R_{3}^{2}-R_{2}^{2}}
$$

Liczba kanałów dyfuzora rurkowego zawiera się zwykle w przedziale $Z_{D r}=$ $=16 \div 34[10,11,14-16]$. Przyjęcie liczby kanałów dyfuzora rurkowego $Z_{D r}$ umożliwia wyznaczenie kolejnych parametrów geometrycznych, takich jak:

1) podziałka dyfuzora rurkowego na wlocie

$$
t_{3}=\frac{\pi D_{3}}{Z_{D r}}
$$


i wylocie dyfuzora

$$
t_{4}=\frac{\pi D_{4}}{Z_{D r}}
$$

2) kąt środkowy osi kanałów dyfuzora w radianach

$$
\theta_{D r}=\frac{2 \pi}{Z_{D r}}
$$

i stopniach

$$
\theta_{D r}^{o}=\frac{360}{Z_{D r}}
$$

Ponieważ punkty styczności osi sąsiednich kanałów dyfuzora $A_{1}$ oraz $A_{2}$ wyznacza kąt środkowy $\theta_{D r}$ :

$$
\Varangle A_{1} O A_{2}=\theta_{D r}
$$

osie sąsiednich kanałów są prostopadłe do ramion $A_{1} O$ oraz $A_{2} O$ kąta środkowego $\theta_{D r}$. Kąt zawarty między osiami sąsiednich kanałów jest zatem równy kątowi środkowemu $\theta_{D r}$ (rys. 4.) jako kąty o ramionach prostopadłych.

Kąt konstrukcyjny wlotowy $\alpha_{3 K}$, zawarty między osią kanału dyfuzora a styczną do okręgu o promieniu $R_{3}$ i wierzchołku w punkcie $B$, ma ramiona prostopadłe do boków $A_{1} O$ oraz $B O$ trójkąta prostokątnego $A_{1} O B$ :

$$
\alpha_{3 K}=\Varangle A_{1} O B,
$$

stąd

$$
\alpha_{3 K}=\arccos \frac{R_{2}}{R_{3}}
$$

Kąt natarcia stanowi różnicę kąta konstrukcyjnego oraz kąta kierunkowego prędkości bezwzględnej na wlocie:

$$
i_{3}=\alpha_{3 K}-\alpha_{3}
$$

W celu uniknięcia oderwań kąt natarcia powinien zawierać się w granicach [4] dla $M_{3}=0,7 \div 1,2, i_{3}=0 \div 3^{\circ}$. Wyższe wartości $M_{3} \cong 1,26$ występują w sprężarkach promieniowych o sprężu $\pi_{\mathrm{s}}^{*}=12$.

Wartości kąta kierunkowego prędkości bezwzględnej $C_{3}$ na wylocie dyfuzora bezłopatkowego $\alpha_{3}$ określa się w trakcie obliczeń tego dyfuzora. Kąt konstrukcyjny na wylocie dyfuzora rurkowego:

$$
\alpha_{4 K}=\Varangle A_{1} O C,
$$

stąd

$$
\alpha_{4 K}=\arccos \frac{R_{2}}{R_{4}}
$$


Należy zauważyć, że ponieważ promień $R_{4}$ okręgu jest zawsze prostopadły do stycznej okręgu o tym promieniu, otwory kanałów dyfuzora rurkowego wierci się pod kątem $\left(90^{\circ}-\alpha_{4 K}\right)$ od kierunku promieniowego (prosta $O C$ ).

Pole powierzchni przekroju pojedynczego kanału dyfuzora rurkowego na wlocie określa się z równania ciągłości:

$$
F_{3,1}=\frac{\dot{m} \sqrt{T_{3}^{*}}}{Z_{D r} s p_{3}^{*} \sin \alpha_{3} q\left(\lambda_{3}\right) K_{m}}
$$

gdzie współczynnik uwzględniający blokadę przekroju przez warstwę przyścienną oraz niejednorodny rozkład prędkości przepływu według autorów prac $[2,10,11]$ dla tego zakresu liczb Macha $M_{3}=1,0 \div 1,2$ może przyjmować wartości $K_{m}=0,82 \div 0,90$, natomiast stała pomocnicza w równaniu ciągłości:

$$
S=\sqrt{\frac{k}{R}}\left(\frac{2}{k+1}\right)^{\frac{k+1}{2(k-1)}}=0,0404 \frac{\mathrm{J}}{\mathrm{kgK}}^{-1 / 2}
$$

W relacji (16) $R$ oznacza indywidualną stałą gazową powietrza. Parametry strumienia w przekroju (3-3) we wzorze (15) są znane z obliczeń dyfuzora bezłopatkowego. Średnica wlotowego kanału cylindrycznego (gardzieli) dyfuzora rurkowego jest wyznaczana z oczywistej relacji:

$$
d_{g}=d_{3}=\sqrt{\frac{4 F_{3,1}}{\pi}}
$$

Powinien więc być spełniony warunek $d_{3} \approx b_{3}$ oraz

$$
t_{3} \approx\left(\frac{d_{g}}{\sin \alpha_{3 K}}+g_{N}\right)
$$

gdzie $g_{N}-$ grubość krawędzi natarcia, $g_{N} \leq 0,08 \mathrm{~mm}$.

Średnica kanału wylotowego (części stożkowej) dyfuzora rurkowego:

$$
d_{4}=d_{3}+2 l_{2} \tan \frac{\theta}{2}
$$

gdzie kąt rozwarcia stożkowej części dyfuzora rurkowego $\theta \leq 8^{\circ}[14,16]$. Wielkość zalecana: $\theta=5 \div 6,5^{\circ}$.

Długość gardzieli dyfuzora rurkowego określa stosunek [3, 4]:

$$
l_{1} / d_{3}=0,5 \div 1,84
$$

W dyfuzorach pierwszej generacji iloraz $l_{1} / d_{3}=1,84$, w drugiej zaś generacji 0,5 . 
Niższe wartości tego stosunku zapewniają w dyfuzorach rurkowych drugiej generacji $\left(l_{1} / d_{3}=0,5\right)$ płynniejszy przebieg przyrostu ciśnienia statycznego wzdłuż długości. Ilustruje to rys. 5. zaczerpnięty z pracy [4]. Współczynnik korekcji ciśnienia $\delta_{o}$ jest stosunkiem ciśnienia otoczenia do ciśnienia normalnego.

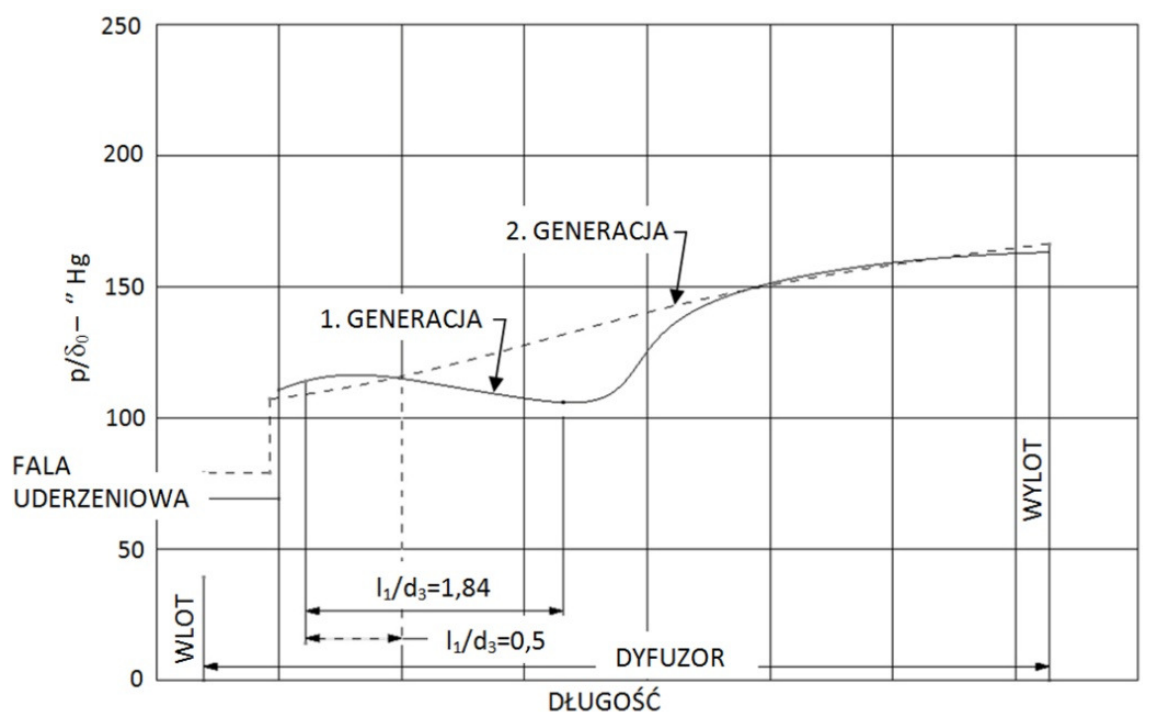

Rys. 5. Porównanie przebiegu ciśnienia statycznego wzdłuż dyfuzora rurkowego pierwszej i drugiej generacji, na podstawie [4]

Fig. 5. Comparison of static pressure distributions along the pipe diffuser of first and second generation, according to [4]

Długość części stożkowej dyfuzora rurkowego można obliczyć z relacji:

$$
l_{2}=L-\left(l_{1}+0,5 d_{g} \sin \alpha_{3 K}+0,5 d_{4} \sin \alpha_{4 K}\right)
$$

Zwykle dla dyfuzorów rurkowych pierwszej i drugiej generacji: $l_{2}+l_{1}=$ $(4 \div 4,5) d_{3}$.

Pole powierzchni przekroju poprzecznego kanału części stożkowej dyfuzora rurkowego na wylocie oblicza się ze wzoru:

$$
F_{4,1}=\frac{\pi d_{4}^{2}}{4}
$$

Stopień dyfuzorowości kanału części stożkowej dyfuzora rurkowego:

$$
\bar{F}_{4,3}=\frac{F_{4,1}}{F_{3,1}}
$$


W formie uwagi można dodać, że jeśli osie kanałów dyfuzora rurkowego byłyby styczne do okręgu o promieniu różnym od $R_{2}[14]-R_{2}{ }_{2} \in\left(R_{2}, R_{3}\right)$, wówczas w relacjach (3), (5), (7) oraz (12) i (14) zamiast wartości promienia $R_{2}$ należy podstawić wartość promienia $R_{2}{ }_{2}$.

\section{Parametry strumienia na wylocie dyfuzora}

Stopień strat ciśnienia spiętrzenia w dyfuzorze rurkowym wyznacza zależność [17]:

$$
\sigma_{3,4}=\frac{p_{4}^{*}}{p_{3}^{*}}=1-\left(\frac{k}{k+1}\right) \xi_{3,4}\left[1-\frac{k-1}{k+1} \lambda_{3}^{2}\right]^{\frac{1}{k-1}} \lambda_{3}^{2}
$$

gdzie współczynnik strat przepływu w dyfuzorze rurkowym

$$
\xi_{3,4}=\frac{l_{r 3,4}}{\frac{C_{3}^{2}}{2}}=\frac{p_{3}^{*}-p_{4}^{*}}{\frac{\rho_{3} C_{3}^{2}}{2}}=\frac{1-\sigma_{3,4}}{\frac{p_{3}^{*} \rho_{3} C_{3}^{2}}{2}}
$$

$\mathrm{W}$ relacji (25) $l_{r 3,4}$ oznacza pracę pokonywania oporów tarcia w dyfuzorze rurkowym.

Wartość stopnia strat $\sigma_{3,4}$ można wyznaczyć, opierając się na względnej wartości strat ciśnienia spiętrzenia w dyfuzorze rurkowym definiowanej następująco:

$$
\Delta \bar{p}_{3,4}=\frac{\Delta p_{3,4}^{*}}{p_{3}^{*}}=\frac{p_{3-}^{*} p_{4}^{*}}{p_{3}^{*}}=1-\sigma_{3,4}
$$

Po uwzględnieniu wzoru (24):

$$
\Delta \bar{p}_{3,4}=\frac{k}{k+1} \xi_{3,4}\left(1-\frac{k-1}{k+1} \lambda_{3}^{2}\right)^{\frac{1}{k-1}} \lambda_{3}^{2}
$$

stopień zaś strat ciśnienia spiętrzenia $\mathrm{w}$ dyfuzorze rurkowym:

$$
\sigma_{3,4}=1-\Delta \bar{p}_{3,4}
$$

Rezultaty badań eksperymentalnych przebiegu funkcji $\Delta \bar{p}_{3,4}=f\left(\alpha_{3}, M_{3}\right)$ przedstawia rys. 6., na którym zaznaczono deformację pola prędkości na wlocie dyfuzora rurkowego uwidocznioną w różnicy wartości liczb Macha $M_{3}$ w obszarze gardzieli. Wyższe prędkości przepływu strumienia występują po stronie podciśnieniowej (dolna tworząca cylindrycznej gardzieli), niższe zaś po stronie nadciśnieniowej (górna tworząca walcowej gardzieli). Różnice wartości liczb Macha na wlocie są szczególnie widoczne w przypadkach $M_{3}>1$, wówczas w obszarze wejściowym części cylindrycznej dyfuzora rurkowego jest generowany układ skośnych fal uderzeniowych zamkniętych falą prostopadłą. 
Ciśnienie spiętrzenia strumienia na wylocie z dyfuzora rurkowego wyznacza się z formuły:

$$
p_{4}^{*}=\sigma_{3,4} p_{3}^{*}
$$

Względna gęstość strumienia masy powietrza na wylocie z dyfuzora:

$$
q\left(\lambda_{4}\right)=\frac{\dot{m} \sqrt{T_{4}^{*}}}{s Z_{D R} p_{4}^{*} F_{4,1} \sin \alpha_{4} K_{m}}
$$

gdzie kąt kierunkowy prędkości bezwzględnej $c_{4}: \alpha_{4}=90^{\circ}$, natomiast $K_{m}=0,9-0,975[2]$.

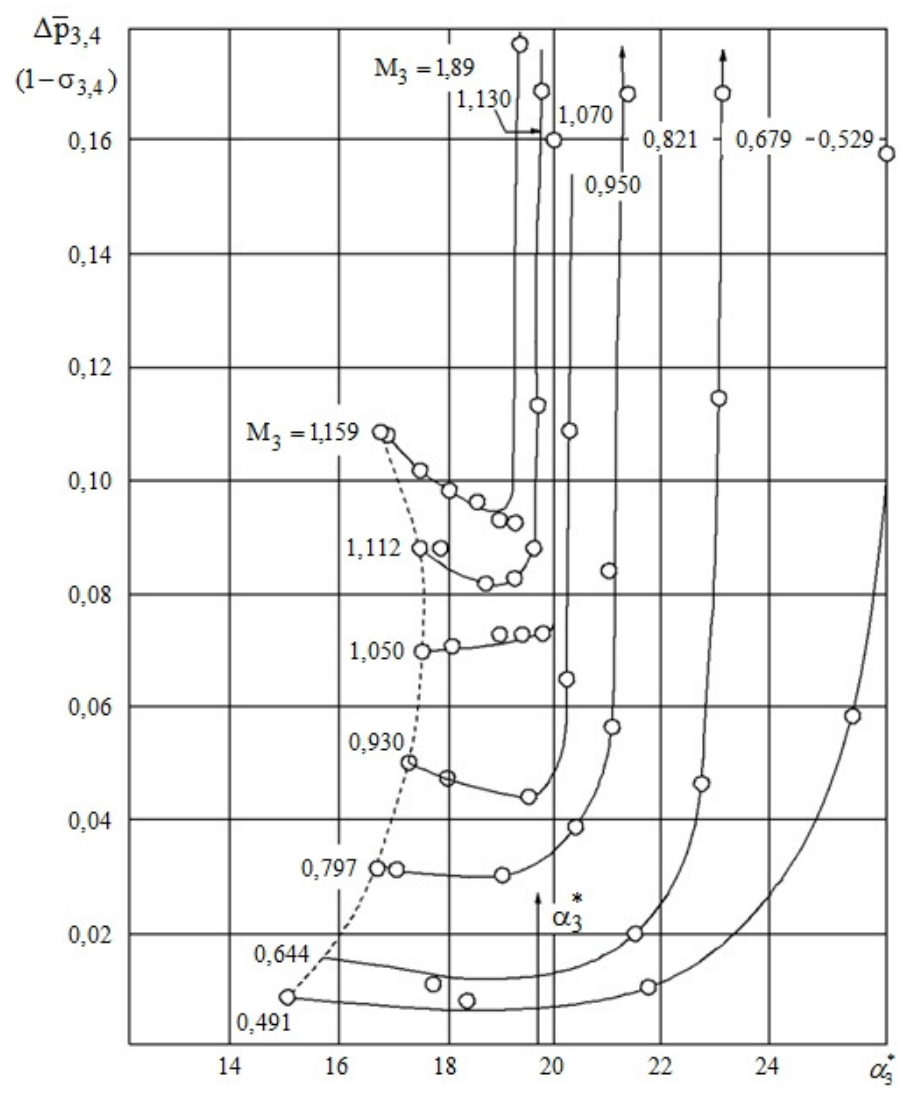

Rys. 6. Zmiana względnej wartości strat ciśnienia spiętrzenia w dyfuzorze rurkowym $\Delta \bar{p}_{3,4} \mathrm{~W}$ zależności od kąta $\alpha_{3}$ wyrażonego w stopniach oraz liczby Macha $M_{3}$ na wlocie, na podstawie [2]

Fig. 6. Thechange of the relative value of stagnation pressure losses in the pipe diffuser $\Delta \bar{p}_{3,4}$ versus inlet angle $\alpha_{3}$ and Mach number $M_{3}$, according to [2] 
Liczba Lavala prędkości bezwzględnej strumienia na wylocie dyfuzora rurkowego $\lambda_{4}$ jest wyznaczana $\mathrm{z}$ zależności definicyjnej względnej gęstości strumienia masy:

$$
q\left(\lambda_{4}\right)=\lambda_{4}\left(1-\frac{k-1}{k+1} \lambda_{3}^{2}\right)^{\frac{1}{k-1}}\left(\frac{k+1}{2}\right)^{\frac{1}{k-1}}
$$

lub za pomocą tablic funkcji gazodynamicznych [18].

Prędkość krytyczna dźwięku w przekroju wyjściowym:

$$
a_{k r 4}=\sqrt{\frac{2 k R}{k+1} T_{4}^{*}}
$$

gdzie

$$
T_{4}^{*}=T_{3}^{*}
$$

Prędkość bezwzględna strumienia na wylocie z dyfuzora rurkowego:

$$
c_{4}=\lambda_{4} a_{k r 4}
$$
wego:

Gęstość powietrza w parametrach spiętrzenia na wylocie z dyfuzora rurko-

$$
\rho_{4}^{*}=\frac{p_{4}^{*}}{R T_{4}^{*}}
$$

Funkcja gazodynamiczna [18]:

- temperatury

$$
\tau\left(\lambda_{4}\right)=1-\frac{k-1}{k+1} \lambda_{4}^{2}
$$

- ciśnienia

$$
\pi\left(\lambda_{4}\right)=\left(1-\frac{k-1}{k+1} \lambda_{4}^{2}\right)^{\frac{k}{k-1}}
$$

- gęstości

$$
\varepsilon\left(\lambda_{4}\right)=\left(1-\frac{k-1}{k+1} \lambda_{4}^{2}\right)^{\frac{1}{k-1}}
$$

Temperatura statyczna strumienia na wyjściu z dyfuzora rurkowego:

$$
T_{4}=\tau\left(\lambda_{4}\right) T_{4}^{*}
$$


Ciśnienie statyczne strumienia na wyjściu z dyfuzora rurkowego:

$p_{4}=\pi\left(\lambda_{4}\right) p_{4}^{*}$

Gęstość statyczna strumienia na wyjściu z dyfuzora rurkowego:

$$
\rho_{4}=\rho_{4}^{*} \varepsilon\left(\lambda_{4}\right)
$$

\section{Uwagi końcowe}

Na rysunku 7. pokazano zmierzone w Instytucie Lotnictwa w Warszawie charakterystyki sprężarki promieniowej z dyfuzorami rurkowymi Vrany o różnej przepustowości. Dyfuzory różniły się między sobą średnicą gardzieli, czyli polem powierzchni części cylindrycznej dyfuzora $F_{g}=F_{3,1} Z_{D R}$. Na podstawie przytoczonych przebiegów sprężu sprężarki w funkcji strumienia masy $\dot{m}_{1 z r}$ i zredukowanej prędkości obrotowej wirnika $n_{S z r}$ można stwierdzić, że wraz ze zmniejszaniem pola powierzchni gardzieli dyfuzora rurkowego granica pracy statecznej przesuwa się w kierunku mniejszych wartości $\dot{m}_{1 z r}$.

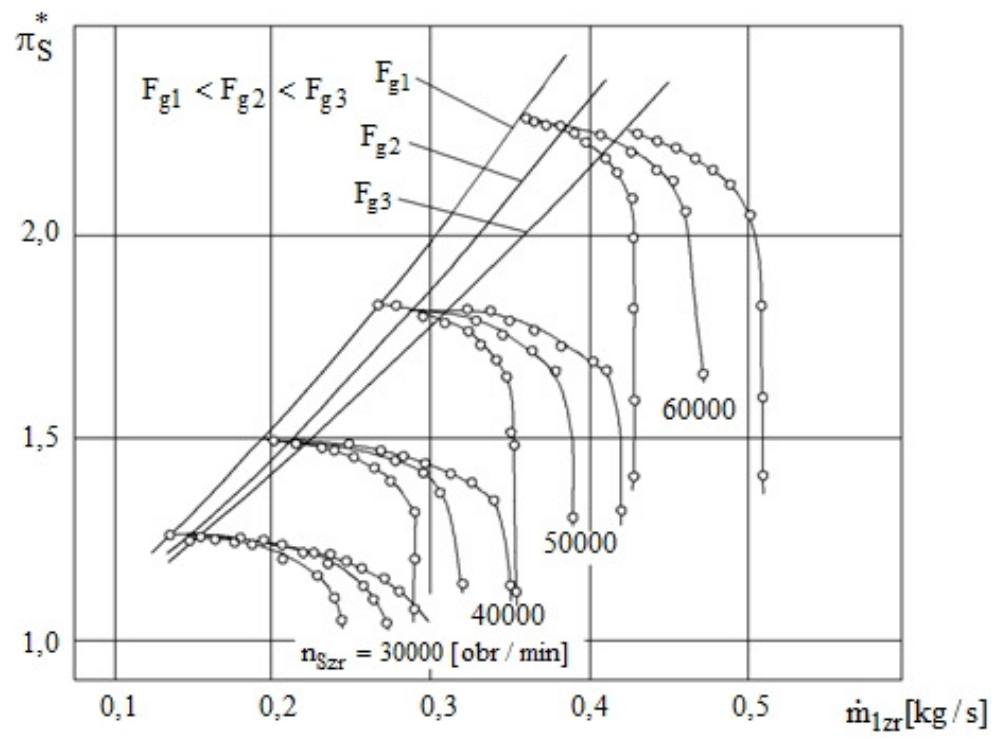

Rys. 7. Charakterystyki sprężarki odśrodkowej z dyfuzorami rurkowymi, na podstawie [19]

Fig. 7. The characteristics of centrifugal compressor with pipe diffusers, according to [19]

Użyteczny zakres pracy sprężarki odśrodkowej z dyfuzorami rurkowymi można również rozszerzyć przez zmniejszenie ich liczby, lecz przyczyny tego 
rozwiązania nie są poznane, a przynajmniej nie są opublikowane [20]. Zagadnienie wpływu liczby dyfuzorów rurkowych na przebieg charakterystyk sprężarki było przedmiotem nielicznych badań eksperymentalnych. Przykładowe wyniki badań na ten temat zaczerpnięte z pracy [15] przedstawiono na rys. 8. Zmniejszenie liczby dyfuzorów rurkowych przesuwa granicę pompażu w lewo, rozszerzając użyteczny zakres pracy sprężarki. Badania eksperymentalne autorów pracy [10] potwierdziły spostrzeżenie Japikse'a. W Instytucie Lotnictwa w Warszawie przeprowadzono także badania porównawcze osiągów dyfuzora rurkowego Vrany z cylindryczną częścią wlotową oraz zmodyfikowanego dyfuzora rurkowego z krzywoliniowym zarysem części wlotowej [13]. Próby przeprowadzono przy trzech wartościach ciśnienia powietrza na wlocie do stoiskowej barokomory wyrównawczej, odpowiadające obliczeniowym warunkom napływu powietrza na wlocie do badanego dyfuzora $p_{3}^{*}=0,27 \mathrm{MPa}$ oraz nieobliczeniowym zakresom pracy dyfuzora dla niższego i wyższego ciśnienia spiętrzenia powietrza na wlocie dyfuzora ( $p_{3}^{*}=0,2 \mathrm{MPa}, p_{3}^{*}=0,296 \mathrm{MPa}$ ), czyli przy niższych i wyższych prędkościach napływu. Określone eksperymentalnie charakterystyki dyfuzora Vrany i dyfuzora zaprojektowanego w Instytucie Lotnictwa w Warszawie (dyfuzor ILot) przedstawiono na rys. 9. Odpowiednie wartości ciśnienia spiętrzenia powietrza na wylocie dyfuzorów $p_{4}^{*}$ naniesiono na oś rzędnych (rys. 9.). Opracowana w Instytucie Lotnictwa konstrukcja dyfuzora rurkowego charakteryzuje się większą sprawnością oraz większym zakresem statecznej pracy w porównaniu z dyfuzorem Vrany.

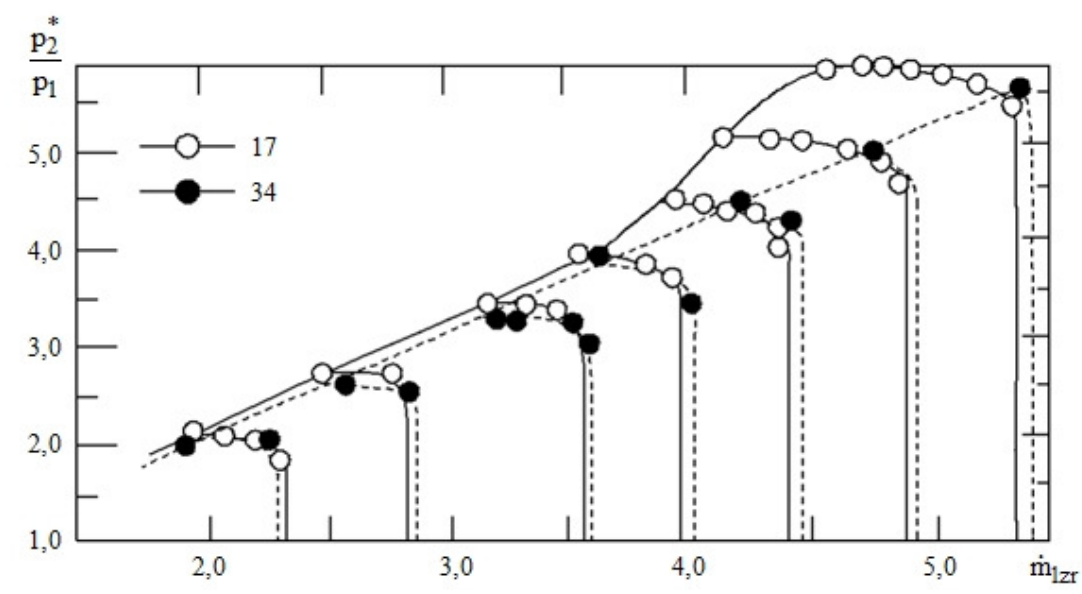

Rys. 8. Porównanie przebiegu charakterystyk sprężarki odśrodkowej z różną liczbą dyfuzorów rurkowych, na podstawie [15]

Fig. 8. Comparison of the course for the characteristics of centrifugal compressor with various numbers of pipe diffusers, according to [15] 


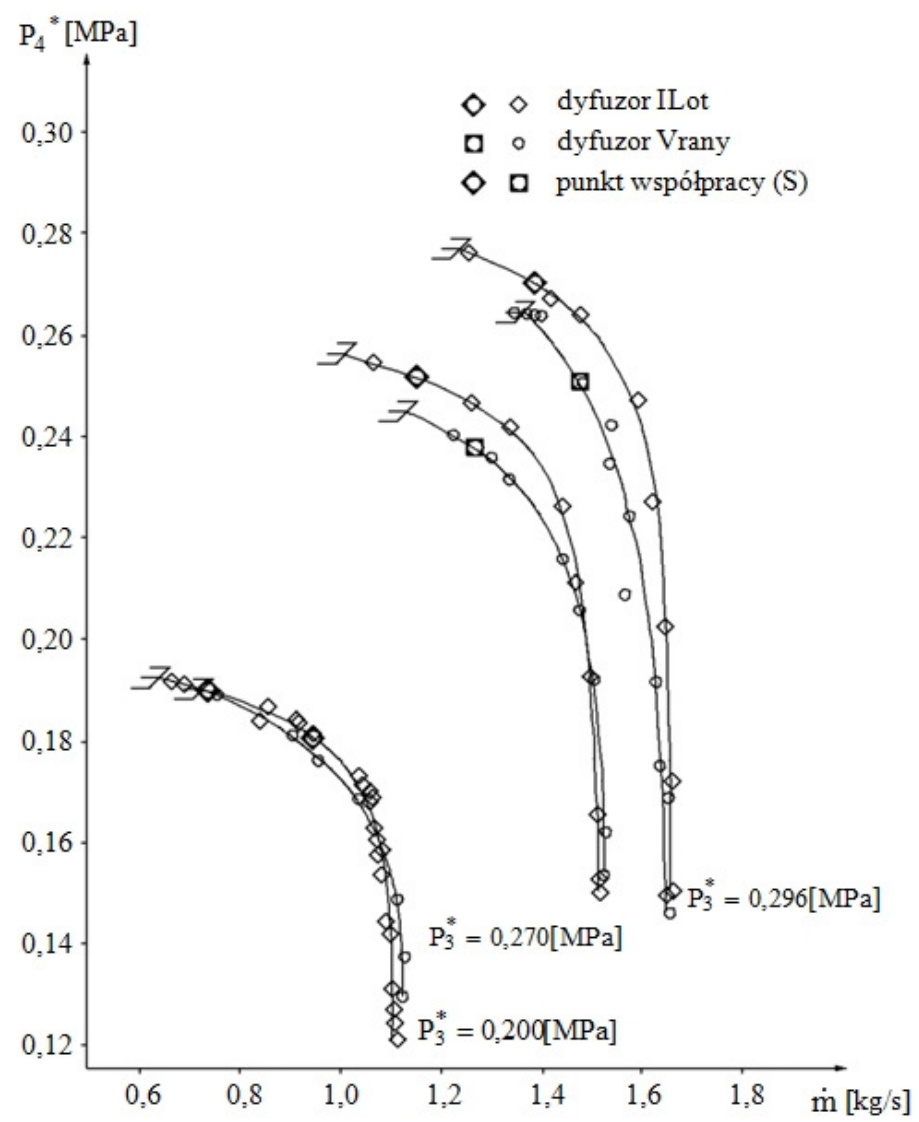

Rys. 9. Zestawienie charakterystyk dyfuzora Vrany i dyfuzora ILot, na podstawie [13]

Fig. 9. Summary characteristics of the Vrana diffuser and the ILot diffuser, according to [13]

\section{Literatura}

[1] PT6 \& ST6 Gas Turbine Engines. Status and Information Report. Pratt \& Whitney Aircraft of Canada, Longueuil 1980.

[2] Kenny D.P.: A comparison of the predicted and measured performance of high pressure ratio centrifugal compressor diffusers. ASME Paper no. 72-GT-54, 1972.

[3] Kenny D.P., Morris R.E.: High pressure ratio centrifugal compressors for small gas turbine engines. $31^{\text {st }}$ Meeting of the Propulsion and Energetics Panel of AGARD. Helicopter Propulsion Systems, Ottawa June 10-14, 1968.

[4] Kenny D.P.: A novel low-cost diffuser for high performance centrifugal compressors transactions of the ASME Journal of Engineering for Power, January 1969, $37-47$. 
[5] Cholscewnikow K.W.: Teorija i rasczot awiacionnych łopatocznych maszin. Maszinostrojenije, Moskwa 1970.

[6] Japikse D.: Centrifugal compressors design and performance. Concepts ETI, 1996.

[7] Tuliszka E.: Sprężarki, dmuchawy i wentylatory. WNT, Warszawa 1976.

[8] Vrana J.C.: Diffuser for centrifugal compressor U. S Patent Office no. 3333762, August 11967.

[9] Jarosz S., Kenny D.P., Vrana J.C.: Maszyna przepływowa odśrodkowa, zwłaszcza sprężarka odśrodkowa. Urząd patentowy PRL. Opis patentowy $\mathrm{nr}$ 71428, 20.09.1974.

[10] Benett I., Tourlidakis A., Elder R.L.: The design and analysis of pipe diffusers for centrifugal compressors. Proc. of the Institution of Mechanical Engineers. Part A. Journal of Power and Energy, 214, 2000, 87-96.

[11] Blair L.W., Russo C.J.: Compact diffusers for centrifugal compressors. Journal of Aircraft, 19 (1), 1982, 46-51.

[12] Yaras M.I., Orsi P.: Effectsof periodic inflow unsteadiness on the time averaged velocity field and pressure recovey of a diffusing bend with strong curvature. Journal of Fluids Engineering, 126 (2), 2004, 229-238.

[13] Kawalec K.: Sprężarka promieniowa o wysokim sprężu. Prace Instytutu Lotnictwa, 151 (4), 1997, 208-214.

[14] Reeves G.B.: Design and performance of selected pipe-type diffusers. ASME Paper No. 77-GT-104, 1977.

[15] Japikse D.: The influence of diffuser inlet pressure fields on the range and durability of centrifugal compressor stages. AGARD Conference, Brussels 1980.

[16] Salvage J.W.: Variable geomtery pipe diffusers. Journal of Turbomachinery, 119, October 1997, 831-838.

[17] Biełousow A.N., Musatkin N.F., Radko W.M.: Teoria i rasczet awiacionnych łopatocznych maszin. Samaskij Gosudarstwiennyj Aerokosmiczeskij Institut, Samara 2003.

[18] Antas S., Lesikiewicz A.: Teoraia silników przepływowych. Funkcje gazodynamiczne. Wydawnictwo Politechniki Rzeszowskiej, Rzeszów 1987.

[19] Białowąs J., Kolarzyk J.: Przebieg i wyniki badań okołodźwiękowych dyfuzorów promieniowych nowego typu. IV Konferencja Naukowo-Techniczna nt. Technologia Przepływowych Maszyn Wirnikowych, Rzeszów 1978, 538-552.

[20] Antas S.: Ocena wpływu wybranych metod modyfikacji maszyn wirnikowych turbinowych silników śmigłowych i śmigłowcowych na zapas statecznej pracy sprężarki. Oficyna Wydawnicza Politechniki Rzeszowskiej, Rzeszów 2006.

\section{PIPE DIFFUSER FOR RADIAL AND AXIAL-CENTRIFUGAL COMPRESSOR}

\section{Abstract}

The low-cost pipe diffuser based upon discrete drilling has been developed by Pratt \& Whitney for high performance radial and axial-centrifugal compressor. These discrete drillings 
are arranged in symmetrical array to mutually intersect in a radial plane so that axis of the pipe diffuser is tangent to the circle created by the exducer radius. The paper presents the original method of calculation of geometric parameters of the pipe diffuser and the proposition of determination of parameters at the outlet of the diffuser. The mentioned methods (for conceptual design of compressor) are based on Pythagorean theorem, equation of energy, equation of continuity, first law of thermodynamics, Euler's moment of momentum equation and definitions used in theory of turbo-machines. The results of the few experimental tests of the pipe diffuser are also presented in the paper.

Keywords: turbine engine, compressor, pipe diffuser

DOI:10.7862/rm.2013.20

Otrzymano/received: 15.04 .2013

Zaakceptowano/accepted: 12.08.2013 